\title{
PENGARUH PENAMBAHAN PURE TERUNG BELANDA (Solanum betacea Cav.) DENGAN GULA TERHADAP MUTU FISIK DAN KIMIA ES KRIM
}

\section{(Effect of Puree Terung Belanda (Solanum betaceum Cav.) with Sugar on Physical Quality and Chemicals of Ice Cream)}

\author{
Nurlaila Abdullah $^{\left.1^{*}\right)}$, Zainal $^{1)}$, dan Nurmadiah ${ }^{1)}$ \\ ${ }^{1 *}$ Program Studi Ilmu dan Teknologi Pangan Departemen Teknologi Pertanian Universitas Hasanuddin \\ Makassar, Indonesia \\ *)email Penulis Korespondensi: penuliskorespondensi@email.com
}

\begin{abstract}
ABSTRAK
Es krim adalah salah satu produk olahan susu dalam bentuk semi beku. Penelitian ini memanfaatkan buah terung belanda (Solanum betacea Cav.) untuk menambah nilai gizi pada produk es krim agar lebih menyehatkan. Tujuan penelitian ini untuk mendapatkan formulasi terbaik antara penambahan pure buah terung belanda dengan gula pada pembuatan es krim, mengetahui karakteristik fisik (overrun dan waktu leleh) serta karakteristik kimia (kadar lemak, kadar protein, kadar serat, total asam dan antosianan) es krim, dan mengetahui daya terima es krim melalui sifat sensori (warna, aroma, rasa dan tekstur). Penelitian ini menggunakan metode Rancangan Acak Lengkap (RAL) secara deskriptif kuantitatif dengan 3 kali ulangan dengan perlakuan $35 \%$ pure terung belanda $+15 \%$ gula $+50 \%$ bahan tambahan (A1), $30 \%$ pure terung belanda $+20 \%$ gula $+50 \%$ bahan tambahan (A2), dan $25 \%$ pure terung belanda $+25 \%$ gula $+50 \%$ bahan tambahan (A3). Hasil penelitian menunjukkan bahwa formulasi terbaik berdasarkan sifat sensori es krim diperoleh daya terima yang paling disukai yaitu perlakuan penambahan $30 \%$ terung belanda $+20 \%$ gula. Berdasarkan hasil analisa statistik menunjukkan bahwa penambahan terung belanda (Solanum betacea Cav.) pada pembuatan es krim berpengaruh nyata pada taraf $5 \%$ terhadap nilai overrun, waktu meleleh, kadar serat, kadar antosianin, dan total asam, tetapi tidak berpengaruh nyata terhadap peningkatan kadar protein dan kadar lemak.
\end{abstract}

Kata Kunci : Terung Belanda, Gula, Es Krim, Nilai Nutrisi.

\begin{abstract}
Ice cream is one of dairy products in the form of semi-frozen. This research utilizes terung belanda (Solanum betaceum Cav.) to increase the nutritional value of ice cream products. The purpose of this research was to get the best formulation between the addition of puree terung belanda (Solanum betaceum Cav.) with addition of sugar on ice cream making, knowing the physical characteristics (overrun and melting time) as well as chemical characteristics (fat content, protein content, fiber content, total acids and anthocyanins) ice cream, and determine the acceptability of ice cream through the sensory properties (color, aroma, flavor and texture). This study used the method Completely Randomized Design (RAL) descriptively quantitative with 3 replicates with $35 \%$ puree terung belanda $+15 \%$ sugar + $50 \%$ additional ingredients (A1), $30 \%$ puree terung belanda $+20 \%$ sugar $+50 \%$ additional ingredients (A2), and $25 \%$ puree terung belanda $+25 \%$ sugar $+50 \%$ additional ingredients (A3). The results show that the best formulation based on sensory properties is treatment of addition of $30 \%$ puree terung belanda $+20 \%$ sugar $+50 \%$ additional ingredients. Based on the results of statistical analysis showed that the addition of terung belanda (Solanum betaceum Cav.) on ice cream making a real effect on the level of 5\% against the value of overrun, melting time, fiber content, anthocyanin levels, and total acid, but no significant effect on the increase of protein content and fat content.
\end{abstract}


Keywords : Terung Belanda (Solanum betaceum Cav.), Sugar, Ice Cream, Nutritional Value

\section{PENDAHULUAN}

Terung belanda (Solanum betacea cav.) termasuk buah klimaterik yang memiliki rasa asam yang sebagian masyarakat tidak suka, namun buah ini memiliki kandungan zat gizi seperti vitamin $\mathrm{A}, \mathrm{C}, \mathrm{E}$, senyawa antioksidan yang dikandung pada $\beta$ Karoten, antosianin dan serat yang baik untuk kesehatan tubuh seperti dapat menurunkan kolesterol, mengobati darah tinggi dan dapat menangkal atau menetralisir radikal bebas (Kumalaningsih, Sri, \& Suprayogi, 2006) Sehingga buah terung belanda dapat berpotensi dijadikan sebagai bahan dalam pengembangan produk pangan yang sehat sekaligus meningkatkan pemanfaatan dan nilai ekonominya dengan diolah menjadi produk es krim.

Es krim salah satu produk olahan susu yang banyak digemari oleh masyarakat dari berbagi kalangan usia. Es krim biasa dikomsumsi sebagai makanan selingan (desert) dan dikelompokkan dalam makanan camilan (snack) yang mempunyai rasa yang manis, lezat, aromanya harum, warnanya menarik, dan tekstur yang lembut. Es krim dibuat dalam bentuk semi beku dengan proses membuat udara terperangkap dalam adonan pada saat pencampuran bahan. Udara yang terperangkap pada es krim memberikan kesan ringan dan dapat memberikan volume lebih. Selain itu es krim dibuat melalui kombinasi proses pembekuan dan agitasi pada bahan-bahan yang terdiri dari produk susu, pemanis, penstabil, pengemulsi, pewarna serta penambah cita rasa (flavor). Peningkatan nilai gizi dan manfaat dalam es krim dapat dilakukan dengan penambahan terung belanda yang mempunyai komponen yang bermanfaat, seperti kandungan pigmen alami serta serat.

Berdasarkan uraian diatas, maka dilakuan penelitian untuk mengetahui pengaruh substitusi penambahan buah terung belanda terhadap mutu fisik, mutu kimia dan mutu sensori es krim serta sebagai bahan tambahan yang berfungsi sebagai penambah cita rasa (flavor), pewarna alami serta komponen tambahan nilai gizi pada es krim yang dapat berisifat antioksidan. Selain itu penelitian ini diharapakan mampu memberikan produk es krim sehat yang ada manfaatnya bagi kesehatan tubuh serta penganekaragaman produk pangan dengan memanfaatkan buah terung belanda.

Produk-produk pangan berlemak seperti produk es krim yang diperkaya dengan penambahan pigmen alami dan serat yang diperoleh dari buah-buahan belum banyak dilakukan. Buah terung belanda merupakan salah satu buah yang memiliki komponen pigmen alami yang baik untuk tubuh jika dikomsumsi

seperti mengandung vitamin, serat dan antosianin, sehingga berpotensi dapat dijadikan sebagai bahan dalam pengembangan produk pangan yang sehat. Selain itu buah terung belanda (Solanum betacea cav.) digunakan dalam penelitian ini karena masih kurang dan terbatasnya pengetahuan akan pengolahannya, hanya dijadikan sebagai bahan pembuatan jus dan dikomsumsi segar atau secara langsung. Maka perlu dilakukan formulasi konsentrasi penambahan buah terung belanda dan bahan lainnya pada pembuatan es krim yang dapat berpengaruh terhadap mutu sifat fisik, kimia dan sifat sensori produk es krim yang dihasilkan.

Tujuan dan kegunaan pada penelitian ini yaitu mendapatkan formulasi terbaik antara penambahan pure buah terung belanda dengan persentase gula pada pembuatan es krim., menganalisis karakteristik fisik meliputi: overrun dan waktu meleleh, serta karakteristik kimia meliputi: kadar lemak, kadar protein, kadar serat, total asam dan antosianin terhadap es krim terung belanda., menganalisis daya terima es krim terung belanda melalui sifat 
sensori (organoleptik terdiri dari warna, aroma, rasa dan tekstur).

Kegunaan penelitian ini adalah sebagai acuan dan bahan informasi bagi konsumen dan masyarakat luas tentang cara pemanfaatan serta pengolahan buah terung belanda dengan dibuat menjadi es krim yang sehat yang baik untuk kesehatan.

\section{METODOLOGI PENELITIAN}

\subsection{Alat}

Alat-alat yang digunakan dalam penelitian ini adalah timbangan analitik, pisau, baskom, wadah, saringan, blender, sendok, hotplate, thermometer, mixer, freezer, stopwatch, gelas kimia, erlenmeyer, bulp dan pipet volume erlenmeyer, bulp dan pipet volume.

\subsection{Bahan}

Bahan-bahan yang digunakan dalam penelitian ini adalah buah terung belanda, susu skim cair, susu full cream cair, whipped cream, karagenan, gula pasir, kuning telur, tissue, aluminum foil, indicator PP (fenolftalein), $\mathrm{NaOH}$, dan aquades.

\subsection{Prosedur Penelitian}

Prosedur penelitian ini terdiri dari dua tahapan yaitu, penelitian pendahuluan dan penelitian utama.

\subsubsection{Penelitian Pendahuluan}

Penelitian tahap pertama dilakukan untuk memperoleh formulasi terbaik es krim terung belanda dengan perlakuan penambahan pure terung belanda dan gula pasir serta bahan tamabahan lainnya. Adapun formulasi penambahan bubur terung belanda, gula pasir dan bahan tambahan lainnya yaitu.

A1 : $50 \%$ pure terung belanda $+15 \%$ gula $+35 \%$ bahan tambahan

A2 : $40 \%$ pure terung belanda $+15 \%$ gula $+45 \%$ bahan tambahan

A3 : $30 \%$ pure terung belanda $+20 \%$ gula $+50 \%$ bahan tambahan
A4 : $20 \%$ pure terung belanda $+25 \%$ gula $+55 \%$ bahan tambahan

A5 : $15 \%$ pure terung belanda $+25 \%$ gula $+60 \%$ bahan tambahan

\subsubsection{Penelitian Utama}

\subsubsection{Pembuatan Pure Terung Belanda}

Buah terung belanda ditimbang selanjutnya dicuci sampai bersih kemudian dipotong menjadi dua bagian. Kerok daging buah dan blender hingga halus kemudian disaring untuk memisahkan bijinya sehingga didapatkan pure terung belanda.

\subsubsection{Pembuatan es Krim}

Semua bahan dicampurkan seperti susu skim cair, susu full cream cair dan kuning telur dipanaskan hingga suhu 80oC, setelah itu didinginkan dan dicampurkan dengan gula pasir, karagenan dan whippy cream kemudian di mixer hingga berbusa selanjutnya ditambahkan pure terung belanda sesuai perlakuan dan dimixer kembali selama 10 menit. Kemudian dilakukan proses aging dalam freezer selama 24 jam pada suhu $7^{\circ} \mathrm{C}$, setelah itu dikeluarkan dari freezer dan ditunggu hingga adonan es krim meleleh dan di mixer kembali selama 15 menit sampai mengembang. Setelah itu dimasukan dalam wadah dan disimpan dalam freezer hingga mengeras, jadilah es krim terung belanda.

\subsubsection{Perlakuan Penelitian}

Perlakuan dalam penelitian ini adalah penambahan pure terung belanda, gula pasir dan bahan tambahan pada es krim dengan 3 perlakuan berikut

$A_{1}: 35 \%$ pure terung belanda $+15 \%$ gula $\mathrm{A}_{2}: 30 \%$ pure terung belanda $+20 \%$ gula $\mathrm{A}_{3}: 25 \%$ pure terung belanda $+25 \%$ gula

\subsubsection{Formulasi Bahan Pembuatan Es Krim}

Tabel 1. Formulasi Bahan Es krim

\begin{tabular}{lcc}
\hline \multirow{2}{*}{ Bahan } & \multicolumn{2}{c}{ Jumlah } \\
\cline { 2 - 3 } & $(\%)$ & (gram) \\
\hline $\begin{array}{l}\text { Pure Terung } \\
\text { belanda }\end{array}$ & $35: 30: 25$ & $140: 120: 100$ \\
\hline
\end{tabular}




\begin{tabular}{lcc}
\hline Gula pasir & $15: 20: 25$ & $60: 80: 100$ \\
\hline Susu full cream & 20 & 80 \\
\hline Susu skim & 20 & 80 \\
\hline Whippy cream & 9,4 & 37,6 \\
\hline Karagenan & 0,4 & 1,6 \\
\hline Kuning telur & 0,2 & 0,8 \\
\hline Jumlah & 100 & 400 \\
\hline
\end{tabular}

\subsection{Rancangan Penelitian}

Data yang diperoleh dari penelitian ini disajikan secara deskriptif kuantitatif dengan menggunakan metode Rancangan Acak Lengkap (RAL) dengan 3 kali ulangan. Data hasil pengamatan dianalisis dengan uji sidik ragam (ANOVA). Jika perlakuan berpengaruh nyata dilanjutan dengan menggunakan uji lanjut Duncan untuk mengetahui data yang berbeda nyata.

\subsection{Parameter Pengujian}

Parameter yang diamati dalam penelitian ini yaitu Overrun (Marshall \& Arbuckle, 2000), Waktu Leleh (Koxholt, Eisenmann, \& Hinrichs, 2001), kadar protein (Sudarmadji, Haryono, \& Suhardi, 1997), kadar lemak (Sudarmadji et al., 1997), kadar serat (Apriyanto, 1989), total asam metode titrasi (AOAC, 1990), antosianin (Giusti \& Wrolstad, 2001), dan uji organoleptik /hedonik (Rahayu, 2001).

\section{HASIL DAN PEMBAHASAN}

\subsection{Overrun}

Overrun merupakan peningkatan volume es krim karena terperangkapnya udara selama proses pembekuan $(\mathrm{H} \&$ Sutherland, 1994).

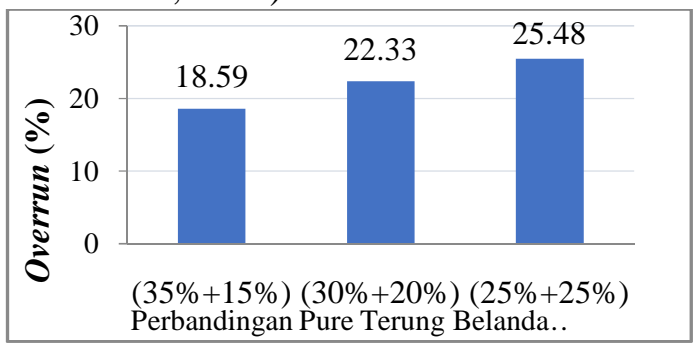

Gambar 1 Hubungan antara Perbandingan Pure Terung Belanda dengan Gula terhadap Nilai Overrun Es Krim
Hasil analisa overrun es krim terung belanda yang dihasilkan menunjukkan bahwa perlakuan dengan penambahan $25 \%$ terung belanda $+25 \%$ gula memiliki nilai overrun tertinggi yaitu $25,48 \%$, sedangkan perlakuan dengan penambahan $30 \%$ terung belanda $+20 \%$ gula sebesar $22,33 \%$ dan penambahan $35 \%$ terung belanda $+15 \%$ gula memiliki nilai overrun terendah yaitu 18,59\%.Berdasarkan hasil analisa Sidik Ragam menunjukkan bahwa adanya perbedaan nyata pada taraf 5\% maka dilanjutkan dengan uji Duncan. Hasil uji Duncan menunjukkan bahwa perlakuan $35 \%$ terung belanda $+15 \%$ gula berbeda nyata dengan perlakuan $30 \%$ terung belanda $+20 \%$ gula dan $25 \%$ terung belanda $+25 \%$ gula. Hal ini disebabkan karena jumlah konsentrasi terung belanda yang ditambahkan memiliki selang penambahan yang semakin tinggi pada perlakuan yang menyebabkan adanya padatan atau partikel dalam adonan es krim, sehingga adonan ketika dimixer menghasilkan busa yang sedikit atau pengembangan volume adonan yang rendah dan mempengaruhi peningkatan nilai overrun bahkan tekstur es krim yang menjadi sedikit kasar.

\subsection{Waktu Leleh}

Waktu leleh merupakan waktu yang dibutuhkan es krim untuk meleleh sempurna pada suhu ruang. Menurut (Marshall \& Arbuckle, 2000) es krim yang bertekstur halus dan rendah total padatannya akan memiliki resistensi pelelehan yang rendah, sehingga mudah meleleh.

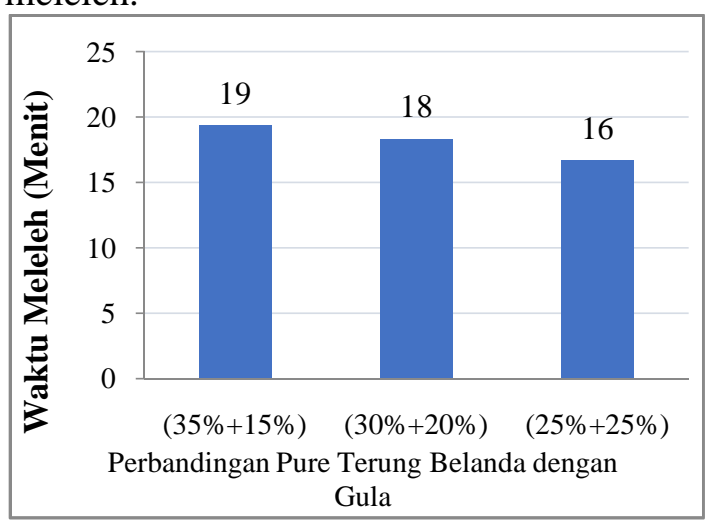


Gambar 2 Hubungan Antara Perbandingan Pure Terung Belanda dengan Gula terhadap Waktu Meleleh Es Krim

Hasil analisa waktu leleh es krim terung belanda yang dihasilkan menunjukkan bahwa perlakuan dengan penambahan $35 \%$ terung belanda $+15 \%$ gula memiliki waktu leleh terlama yaitu 19 menit, sedangkan perlakuan penambahan $30 \%$ terung belanda $+20 \%$ gula memiliki waktu leleh 18 menit, dan penambahan $25 \%$ terung belanda $+25 \%$ gula memiliki waktu leleh tercepat yaitu 16 menit. Berdasarkan hasil analisa Sidik Ragam menunjukkan bahwa adanya perberbedaan nyata pada taraf 5\% maka dilanjutkan dengan uji Duncan. Hasil uji Duncan menunjukkan bahwa perlakuan $35 \%$ terung belanda + $15 \%$ gula dan $30 \%$ terung belanda $+20 \%$ gula berbeda nyata dengan $25 \%$ terung belanda $+25 \%$ gula. Hal ini disebakan adanya konsentarsi penambahan terung belanda dan gula yang semakin tinggi sehingga menyebabkan waktu pelelehan semakin lama. Daya leleh es krim berkaitan dengan tekstur dan kekentalan adonan es krim (ICM). Kekentalan dipengaruhi oleh bahan-bahan penyusun es krim, salah satunya buah terung belanda (Padaga \& Sawitri, 2005), menyatakan bahwa kecepatan meleleh es krim dipengaruhi oleh komposisi bahan-bahan yang digunakan pada pembuatan ICM.Hasil uji waktu leleh es krim yang diperoleh telah memenuhi SNI yaitu 15-25 menit.

\subsection{Kadar Protein}

Protein merupakan salah satu zat gizi makanan yang mempunyai fungsi yang tidak dapat digantikan oleh zat gizi lain, yaitu membangun dan memelihara sel-sel serta jaringan tubuh (Almatsier, 2004).

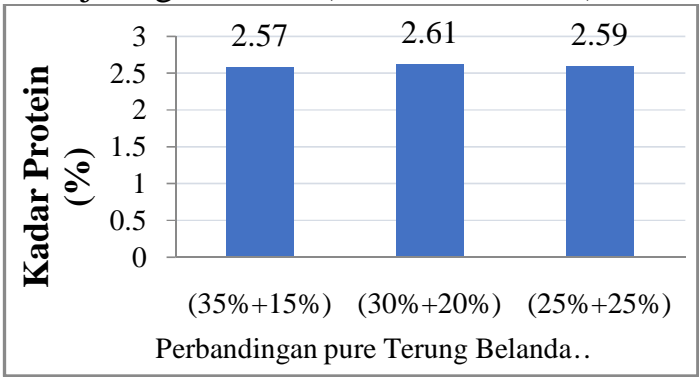

Gambar 3 Hubungan Antara Perbandingan Pure Terung Belanda dengan Gula terhadap Kadar Protein Es Krim.

Hasil analisa kadar protein es krim yang dihasilkan menunjukkan bahwa perlakuan penambahan $35 \%$ terung belanda $+15 \%$ gula yaitu2,57\%, perlakuan $30 \%$ terung belanda $+20 \%$ gula yaitu $2,61 \%$ dan perlakuan $25 \%$ terung belanda $+25 \%$ gula yaitu2,59\%.Berdasarkan hasil analisis sidik ragam menunjukkan bahwa tidak adanya perbedaan nyata pada taraf 5\% sehingga tidak dilanjutkan dengan uji Duncan. Meskipun terung belanda juga memiliki kadar protein menurut (Kumalaningsih et al., 2006), sebesar 1,4\%-2\% namun tidak terlalu berpengaruh terhadap kadar protein yang dihasilkan. Hal ini disebabkan oleh pengaruh protein yang berasal dari bahan tamabahan dalam pembuatan es krim terutama penambahan susu yang ditambahkan dengan persentase yang sama pada ketiga perlakuan. Menurut (Winarno, 1997) bahwa susu mengandung kasein yang merupakan protein utama pada susu yaitu sebesar $80 \%$ dari total protein.

\subsection{Kadar Lemak}

Lemak merupakan salah satu zat gizi yang penting untuk menjaga kesehatan tubuh, penambahan lemak dan minyak mempunyai

tujuan diantaranya untuk penambahan kalori, memperbaiki tekstur dan cita rasa suatu bahan pangan (Winarno, 1997).

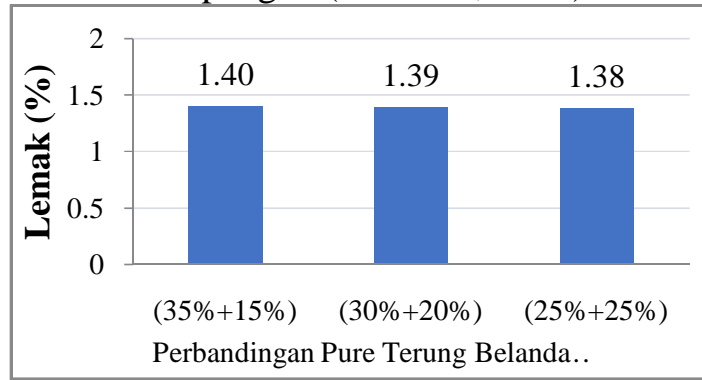

Gambar 4 Hubungan antara Perbandingan Pure Terung Belanda dengan Gula terhadap Kadar Lemak Es Krim.

Hasil analisa kadar lemak es krim yang dihasilkan menunjukkan bahwa kadar lemak es krim yang diperoleh hampir sama 
pada ketiga perlakuan. Kadar protein es krim pada perlakuan penambahan $35 \%$ terung belanda $+15 \%$ gula sebesar $1,40 \%$, penambahan $30 \%$ terung belanda $+20 \%$ gula sebesar $1,39 \%$ dan penambahan $25 \%$ terung belanda $+25 \%$ gula sebesar $1,38 \%$. Berdasarkan hasil analisa Sidik Ragam menunjukkan bahwa tidak adanya perberbedaan nyata pada taraf 5\% maka tidak dilanjutkan dengan uji Duncan. Penambahan terung belanda tidak berpengaruh terhadap kadar lemak yang diperoleh, karena pada terung belanda memiliki kadar lemak yang cukup sedikit (Kumalaningsih et al., 2006) buah terung belanda memiliki komposisi kadar lemak sebesar 0,1\%-0,6\% setiap 100 gram. Kadar lemak yang diperoleh berasal dari bahan tambahan seperti susu dan whippy yang ditambahakan dalam proses pembuatan es krim.

\subsection{Kadar Serat}

Serat pangan merupakan komponen dari tanaman yang terdapat dalam berbagai sayuran dan buah-buahan (Winarno, 2008)

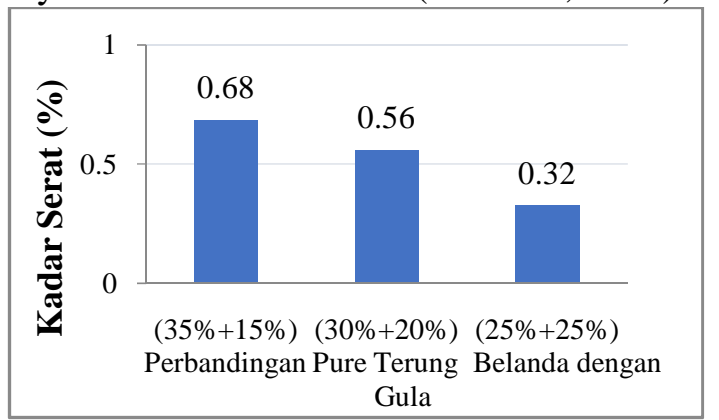

Gambar 5 Hubungan antara Perbandingan Pure Terung Belanda dengan Gula terhadap Kadar SeratEs Krim

Hasil analisa kadar serat es krim yang dihasilkan menunjukkan bahwa perlakuan penambahan $35 \%$ terung belanda $+15 \%$ gula memiliki kadar serat tertinggi yaitu $0,68 \%$ sedangkan penambahan $30 \%$ terung belanda $+20 \%$ gula sebesar $0,56 \%$ dan penambahan $25 \%$ terung belanda $+25 \%$ gula memiliki kadar serat terendah yaitu $0,32 \%$.Berdasarkan hasil analisa SidikRagam menunjukkan adanya perberbedaan nyata pada taraf 5\% maka dilanjutkan dengan uji Duncan. Hasil uji duncan menunjukkan bahwa perlakuan penambahan35\% terung belanda $+15 \%$ gula berbeda nyata dengan perlakuan penambahan $30 \%$ terung belanda $+20 \%$ gula dan berbeda nyata dengan penambahan $25 \%$ terung belanda $+25 \%$ gula. Hal ini disebabkan semakin meningkat penambahan buah terung belanda maka kadar serat yang dihasilkan semakin tinggi

Secara siginifikan, karena buah terung belanda memiliki kadar serat cukup tinggi. Menurut (Kumalaningsih et al., 2006), buah terung belanda memiliki serat sebanyak $1,4-4,7 \%$ dari 100 gram terung belanda.

\subsection{Antosianin}

Antosianin adalah pigmen tumbuhan yang memberi warna biru, merah, dan ungu pada bagian daun dan buah

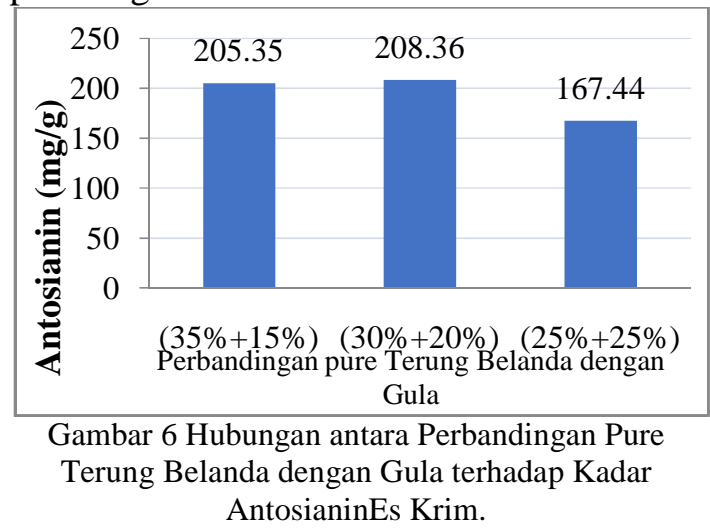

Hasil analisa kadar serat es krim yang dihasilkan menunjukkan bahwa Rata-rata kadar antosianin yang diperoleh berkisar antara 167,44 sampai 205,35 mg/gram. Berdasarkan hasil analisa Sidik Ragam menunjukkan adanya perbedaan nyata pada taraf 5\% maka dilanjutkan dengan uji Duncan. Hasil uji duncan menunjukkan bahwa perlakuan penambahan $35 \%$ terung belanda $+15 \%$ gula tidak berbeda nyata dengan penambahan $30 \%$ terung belanda + $20 \%$ gula tetapi berbeda nyata dengan penambahan $25 \%$ terung belanda +255 gula. Hal ini disebabkan karena pada buah terung belanda memiliki pigmen antosianin. Menurut (Astawan \& Andreas, 1997) menyatakan buah terung belanda banyak mengandung antosianin. Antosianin yang 
termasuk kedalam golongan flavonoid yang dapat dimanfaatkan sebagai pewarna makanan dan juga berfungsi sebagai antioksidan. Antosianin adalah pigmen tumbuhan yang memberi warna biru, merah, dan ungu pada bagian daun dan buah.

\subsection{Total Asam}

Pengujian total asam pada produk es krim terung belanda dilakukan untuk mengetahui kandungan asam pada es krim

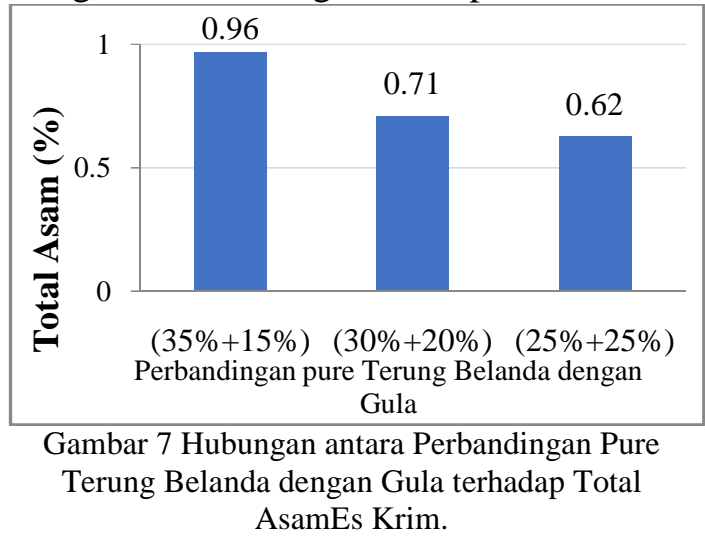

Hasil analisa total asam es krim yang dihasilkan menunjukkan bahwa rerata total asamberkisar antara 0,6\%0,9\%.Berdasarkan hasil analisa Sidik Ragam menunjukkan adanya perberbedaan nyata pada taraf 5\% maka dilanjutkan dengan uji Duncan. Hasil uji duncan menunjukkan bahwa perlakuan penambahan $35 \%$ terung belanda $+15 \%$ gula berbeda nyata dengan penambahan $30 \%$ terung belanda $+20 \%$ gula dan penambahan $25 \%$ terung belanda + $20 \%$ gula.Hal ini disebabkan adanya peningkatan konsentarsi penambahan terung belanda sehingga total asam yang dihasilkan semakin tinggi. Total asam yang diperoleh bersal dari buah terung belanda yang ditambahkan. Menurut (Kumalaningsih et al., 2006), buah terung belanda memiliki kadar keasaman yang tertitrasi sebanyak 1,0-2,6 (g/ $100 \mathrm{~g})$.

\subsection{Pengujian Organoleptik}

\subsubsection{Warna}

Warna es krim sangat mempengaruhi persepsi konsumen tentang rasa dan kualitas es krim itu sendiri. Warna natural yang berasal dari tanaman telah lama digunakan sebagai pewarna makanan yang memberikan kesan menyehatkan dan memiliki kelarutan yang baik (Clarke, 2012), Pengujian warna digunakan dalam pengujian organoleptik karena warna mempunyai peranan penting terhadap tingkat penerimaan produk secara visual. Suatu bahan pangan meskipun dinilai enak, tetapi memiliki warna yang tidak menarik atau memberi kesan telah menyimpang dari warna yang seharusnya, maka seharusnya tidak akan dikonsumsi (Winarno, 2002). Hasil analisa Sidik Ragam menunjukkan adanya perbedaan nyata pada taraf 5\% maka dilanjutkan dengan uji Duncan. Hasil uji Duncan menunjukkan bahwa perlakuan $35 \%$ terung belanda $+15 \%$ gula tidak berbeda nyata dengan $30 \%$ terung belanda $+20 \%$ gula tetapi berbeda nyata pada $25 \%$ terung belanda $+25 \%$ gula.



Gambar 8 Hubungan antara Perbandingan Pure Terung Belanda dengan Gula terhadap WarnaEs Krim.

Berdasarkan hasil pengujian organoleptik dengan metode hedonik pada warna es krim terung belanda diperoleh nilai rata-rata pada perlakuan $35 \%$ terung belanda $+15 \%$ gula yaitu $4,13 \%$ yang berarti disukai panelis. Perlakuan 30\% terung belanda $+20 \%$ gula yaitu $3,83 \%$ yang berari disukai panelis, sedangakan perlakuan $25 \%$ terung belanda $+25 \%$ gula yaitu $3,35 \%$ yang berarti agak disukai panelis. Hal ini disebabkan semakin banyak penambahan konsentrasi terung belanda akan menyebabkan peningkatan warna merah pada produk es krim yang dihasilkan. Warna merah muda yang dihasilkan berasal 
dari terung belanda yang mengandung antosianin yang termasuk golongan flavonoid. Menurut (Astawan, 2009). antosianin yang terdapat pada terung belanda merupakan kelompok zat warna berwarna kemerahan yang larut dalam air dan dapat dimanfaatkan sebagai pewarna makanan dan minuman.

\subsubsection{Rasa}

Rasa merupakan faktor yang sangat penting dalam menentukan keputusan akhir konsumen untuk menerima atau menolak suatu produk pangan. Rasa dapat diciptakan dari sumber alami seperti tanaman atau sintetis. Hasil analisa Sidik Ragam menunjukkan adanya perbedaan nyata pada taraf 5\% maka dilanjutkan dengan uji Duncan. Hasil uji Duncan menunjukkan bahwa perlakuan $35 \%$ terung belanda + $15 \%$ gula berbeda nyata dengan perlakuan $30 \%$ terung belanda $+20 \%$ gula dan perlakuan $25 \%$ terung belanda $+25 \%$ gulatetapi perlakuan $30 \%$ terung belanda + $20 \%$ gula dan perlakuan $25 \%$ terung belanda $+25 \%$ gula tidak berbeda nyata.

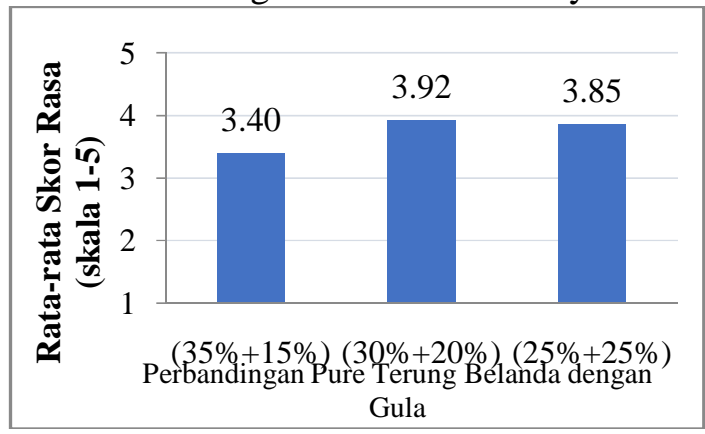

Gambar 9 Hubungan antara Perbandingan Pure

Terung Belanda dengan Gula terhadap RasaEs Krim.

Berdasarkan Hasil pengujian organoleptik dengan metode hedonik pada rasa es krim terung belanda diperoleh nilai rata-rata pada perlakuan $35 \%$ terung belanda $+15 \%$ gula memilik skor $3,4 \%$ yang berarti disukai panelis, perlakuan $30 \%$ terung belanda $+20 \%$ gula memiliki skor $3,92 \%$ yang berari disukai panelis dan perlakuan $25 \%$ terung belanda $+25 \%$ gula memiliki skor $3,85 \%$ yang berarti disukai panelis. Hal ini disebabkan adanya penambahan konsentrasi terung belanda yang semakin tinggi pada setiap perlakuan,terutama dengan penambahan $35 \%$ terung belanda $+15 \%$ gula yang memiliki rasa asam sehingga panelis lebih menyukai es krim dengan rendah keasaman dan kadar gula tinggi. Rasa asam yang dihasilkan dari terung belanda berasal kandungan askorbat (vitamin C) yang terkandung. Menurut (Kumalaningsih et al., 2006), bahwa terung belanda adalah tanaman yang memiliki kandungan kadar keasaman yang tertitrasi sebesar1,0-2,6 g/100 gram. Tanaman ini juga memiliki kandungan vitamin $\mathrm{C}$ dan zat besi yang sempurna.

\subsubsection{Tekstur}

Tekstur es krim ditentukan dengan menggunakan indera peraba, perasa dan penglihatan ketika menilai penampilan dan mencicipi es krim tersebut. Tekstur yang diinginkan dalam es krim adalah lembut, creamy, dan homogenous (Marshall \& Arbuckle, 2000), Hasil analisa Sidik Ragam menunjukkan bahwa semua perlakuan berbedan nyata pada taraf $5 \%$ maka dilanjutkan dengan uji Duncan. Hasil uji Duncan menunjukkan bahwa perlakuan $35 \%$ terung belanda : $15 \%$ gula berbeda nyata dengan perlakuan $25 \%$ terung belanda : $25 \%$ gula dan berbeda nyata juga dengan perlakuan $30 \%$ terung belanda : $20 \%$ gula.

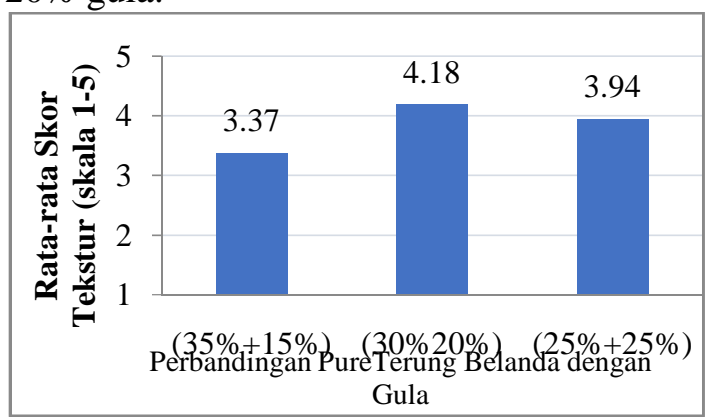

Gambar 10 Hubungan antara Perbandingan Pure

Terung Belanda dengan Gula terhadap TeksturEs Krim.

Berdasarkan Hasil pengujian organoleptik dengan metode hedonik pada tekstur es krim diperoleh nilai rata-rata pada perlakuan $35 \%$ terung belanda $+15 \%$ gula memiliki skor $3,37 \%$ yang berarti agak 
disukai panelis, perlakuan $30 \%$ terung belanda $+20 \%$ gula memiliki skor $4,18 \%$ yang berari disukai panelis, dan perlakuan $25 \%$ terung belanda $+25 \%$ gula memiliki skor $3,94 \%$ yang berarti disukai panelis. Hal ini disebabkan tingginya padatan atau partikel dalam adonan yang berasal dari buah terung belanda yang menyebabkan tekstur es krim menjadi kasar, terutama pada penambahan35\% terung belanda + $15 \%$ gula dimana penambahan terung belanda yang tinggi sehingga panelis kurang menyukai. Menurut (Chen, Wolle, \& Sommer, 2009), bahwa penggunaan konsentrasi buah-buahan yang agak tinggi di dalam es krim (15-24\%), menyebabkan tekstur kasar karena partikel buah tersebut.

\subsubsection{Aroma}

Aroma atau bau-bauan dapat dikenali jika dalam bentuk uap (volatil), dan molekul-molekul komponen bau tersebut harus menyentuh silia sel olfaktori, dan diteruskan ke otak (Winarno, 2002) Hasil analisa Sidik Ragam menunjukkan bahwa semua perlakuan tidak berbedan nyata pada taraf $5 \%$ maka tidak dilanjutkan dengan uji Duncan.

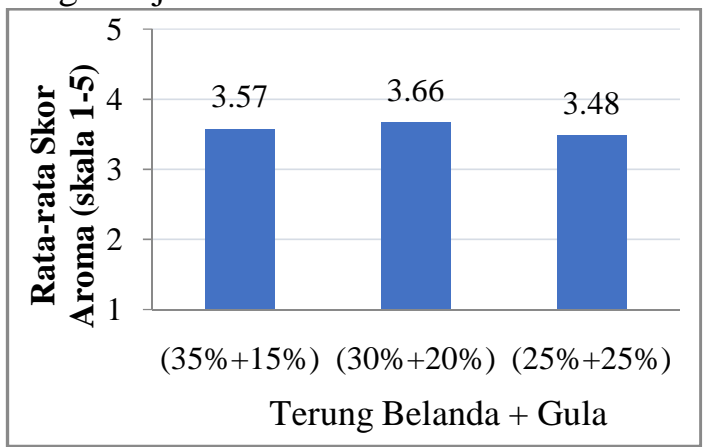

Gambar 11 Hubungan antara Perbandingan Pure Terung Belanda dengan Gula terhadap Aroma Es Krim.

Berdasarkan hasil pengujian organoleptik dengan metode hedonik pada aroma es krim diperoleh nilai rata-rata pada perlakuan $35 \%$ terung belanda $+15 \%$ gula memiliki skor $3,57 \%$ yang berarti disukai panelis. Perlakuan $30 \%$ terung belanda + $20 \%$ gula memiliki skor $3,66 \%$ yang berarti disukai panelis sedangkan perlakuan $25 \%$ terung belanda $+25 \%$ gula memiliki skor
3,48\% yang berarti agak disukai panelis. Aroma pada es krim yang dihasilkan dipengaruhi oleh bahan yang digunakan dalam pencampuran adonan es krim. Hal ini disebabkan adanya penambahan susu yang memiliki persentase yang sama terhadap ketiga perlakuan, sehingga aroma susu yang dihasilkan sangat terasa dibandingkan aroma dari buah terung belanda yang ditambahkan. Menurut (Setyaningsih, Ariyantono, \& Sari, 2010) bahwa penguat cita rasa adalah suatu zat bahan tambahan yang ditambahkan kedalam makanan yang dapat memperkuat aroma dan rasa.

\section{KESIMPULAN}

1. Berdasarkan hasil penelitian didapatkan formulasi pembuatan es krim terbaik yaitu perlakuan $30 \%$ pure terung belanda $+20 \%$ gula $+50 \%$ bahan tambahan .

2. Hasil analisa statistik menunjukkan bahwa penambahan terung belanda pada pembuatan es krim berpengaruh nyata pada taraf $5 \%$ terhadap nilai overrun, waktu meleleh, kadar serat, kadar antosianin, dan total asam, tetapi tidak berpengaruh nyata terhadap peningkatan kadar protein dan kadar lemak.

3. Hasil analisa sifat sesori pada es krim terung belanda diperoleh daya terima yang paling disukai panelis dari segi rasa, tekstur dan aroma yaitu perlakuan penambahan $30 \%$ pure terung belanda + $20 \%$ gula, dengan nilai rata-rata pada rasasebesar3,92\%, tekstursebesar4,21\%, aroma sebesar 3,66\%. Sedangkan dari segi warna yang paling disukai panelis yaitu perlakuan penambahan $35 \%$ pure terung belanda $+15 \%$ gula, dengan nilai rata-rata pada warna sebesar $4,13 \%$.

\section{DAFTAR PUSTAKA}

Almatsier. (2004). Prinsip Dasar Ilmu Gizi. Jakarta: gramedia Pustaka Utama.

AOAC. (1990). Official Methods of Analysis of AOAC International. In Association of Official Analysis Chemists International. 
https://doi.org/10.3109/155636576089 88149

Apriyanto. (1989). Analisa Pangan. Bogor.: IPB Press.

Astawan. (2009). Tepung tapioka Manfaat dan cara Pembuatannya. Jakarta: Penebur Swadaya.

Astawan, \& Andreas. (1997). Khasiat Warna-Warni Makanan. Jakarta: PT Gramedia Pustaka Utama.

Chen, C., Wolle, D., \& Sommer, D. (2009). The Sensory Evaluation of Dairy Products. The Sensory Evaluation of Dairy Products. https://doi.org/10.1007/978-0-38777408-4

Clarke, C. (2012). Science of Ice Cream (2nd Edition). Royal Society of Chemistry.

Giusti, M. M., \& Wrolstad, R. E. (2001). Characterization and measurement of anthocyanins by UV- Visible spectroscopy. In Current Protocols in Food Analytical Chemistry. https://doi.org/10.1002/0471142913.fa f0102s00

H, V., \& Sutherland, J. (1994). Milk and Milk Product. Technology, Chemistry, and Microbiology. Chapman and Hall.

Koxholt, M. M. R., Eisenmann, B., \& Hinrichs, J. (2001). Effect of the Fat Globule Sizes on the Meltdown of Ice Cream. Journal of Dairy Science. https://doi.org/10.3168/jds.S00220302(01)74448-7

Kumalaningsih, Sri, \& Suprayogi. (2006). Tamarillo (Terung Belanda) TanamanBerkhasiat Penyedia Antioksidan Alami. Surabaya: Trubus Agrisarana.

Marshall, \& Arbuckle. (2000). Ice Cream, 5th Edition. New York: Chapman and Hall.

Padaga, \& Sawitri. (2005). Es Krim yang Sehat. Surabaya: Trubus Agrisarana.

Rahayu. (2001). Penuntun Praktikum Penilaian Organoleptik. IPB.Bogor.

Setyaningsih, Ariyantono, \& Sari. (2010). Analisa Sensori untuk Industri Pangan dan Agro. Bogor: IPB.Bogor.
Sudarmadji, Haryono, \& Suhardi. (1997). Prosedur Analisa Untuk Bahan Makanan dan Pertanian. Yogyakarta: Liberty Press.

Winarno. (1997). kimia pangan dan Gizi. Jakarta: PT Gramedia Pustaka Utama.

Winarno. (2002). Kimia Pangan dan Gizi. Jakarta: PT. Gramedia Pustaka Utama.

Winarno. (2008). Kimia Pangan dan Gizi. Bogor.: bio:Press. 